Pediat. Res. 4: 345-351 (1970)

Fetal homeostasis

hyperkalemia

hyponatremia malnutrition

placenta

potassium

sodium

\title{
Fetal Homeostasis in Maternal Malnutrition: Potassium and Sodium Deficiency in Rats
}

\author{
Joseph Dancis ${ }^{[12]}$ and Dawn Springer \\ Department of Pediatrics, New York University School of Medicine, New York, New York, USA
}

\begin{abstract}
Extract
Maternal rats fed a diet deficient in potassium $(K)$ during pregnancy were depleted of $\mathrm{K}$ so that the plasma level of $\mathrm{K}$ fell to one-half the normal value and the concentration in maternal muscle fell by about $30 \%$. The $\mathrm{K}$ concentration in fetal plasma under these circumstances did not change significantly, but that in fetal tissues (placenta and fetus) decreased by roughly $10 \%$ (fig. 1 , table III). Maternal hyperkalemia, induced by a sodium-deficient diet or produced by infusions of $\mathrm{K}$ (table IV) induced a fetal hyperkalemia (fig. 1). Maternal hyponatremia caused proportional hyponatremia in the fetus (slope $=0.60$, correlation coefficient $=0.91$ ) (fig. 2 ); the sodium content of the fetus was also reduced in maternal hyponatremia (fig. 3 ).
\end{abstract}

\section{Speculation}

Deserving of particular emphasis is the contrast between the effect of maternal hyperkalemia and hypokalemia on the level of potassium in the fetal blood. This difference in response raises questions concerning the mechanism of placental transport of potassium. It would be of interest to determine if the placenta protects the fetus against other maternal ion deficiencies.

\section{Introduction}

Mammalian pregnancy offers the fetus the advantage of a controlled environment during a critical period of growth and development. The control is provided primarily by the homeostatic mechanisms of the mother which maintain the composition of her blood, under normal conditions, within relatively narrow limits. It is suspected that the placenta, through its array of active transport mechanisms, may serve as a second line of defense.

These investigations have been designed to study the mechanisms by which the fetus is protected when the mother is subjected to the severe stress that results from specific nutritional deficiencies. The present studies concentrate on the effects of potassium (K) and sodium $(\mathrm{Na})$ deficiences. Acute elevations of $\mathrm{K}$ levels in the plasma of the mother were also induced because of questions raised by some of the nutritional studies.

The rat was chosen as the experimental animal because extensive nutritional information about this animal was already available, because of the ease of obtaining modified diets, and because the rapid rate of growth of the total fetal mass presents particularly severe demands on the dam. 
Materials and Methods

The sodium-deficient test diet for rats (Hartroft formula) [2], without the salt mixture, was obtained commercially [7]. The salts were mixed in our laboratory and $40 \mathrm{~g}$ of the salt mix were added to $955 \mathrm{~g}$ of the basic diet (table I).

To complete the normal diet, $5 \mathrm{~g} \mathrm{NaCl}$ and $12 \mathrm{~g}$ $\mathrm{KCl}$ were added, providing $160 \mathrm{mEq} \mathrm{K}$ and $150 \mathrm{mEq}$ $\mathrm{Na} / \mathrm{kg}$ of formula. For the potassium-deficient diet, $\mathrm{KGl}$ was omitted. For the sodium-deficient diet, $\mathrm{Na}_{2} \mathrm{HPO}_{4}$ was omitted from the basic salt mixture and only $0.81 \mathrm{~g} \mathrm{NaCl}$ was added to each kilogram of formula (instead of $5 \mathrm{~g}$ ). This provided $14 \mathrm{mEq} \mathrm{Na}$ and $160 \mathrm{mEq} \mathrm{K} / \mathrm{kg}$ of formula.

Pregnant rats were purchased [8]. The special diets were offered ad libitum usually beginning on day 2 of pregnancy, occasionally as late as day 5 . Blood samples from the mother were obtained from the tail vein. The ammonium salt of heparin was used as an anticoagulant. On day 21 of gestation, the animals were anesthetized by injecting intraperitoneally $0.15 \mathrm{ml}(60 \mathrm{mg} / \mathrm{ml})$ of sodium pentobarbital, and a hysterotomy performed. The fetuses were delivered into a $\mathrm{NaCl}$ bath $(0.154$ M equivalent to $0.9 \mathrm{~g} / 100 \mathrm{ml}$ ) kept at $37^{\circ}$. Fetuses were removed individually and dried. Blood samples were collected from the axillary vessels into heparinized (ammonium salt) microcollecting tubes. The blood from two normal fetuses were pooled. Fetuses from mothers fed diets deficient in $\mathrm{K}$ and $\mathrm{Na}$ were smaller so that blood from three or four fetuses was pooled.
Muscle samples from dams were obtained from the quadriceps.

\section{Infusion Studies}

Solutions of $\mathrm{KCl}(0.154 \mathrm{~m}$ equivalent to $1.15 \mathrm{~g} /$ $100 \mathrm{ml})$ and $\mathrm{CaCl}_{2}(0.11 \mathrm{M}$ equivalent to $1.22 \mathrm{~g} /$ $100 \mathrm{ml}$ ) were mixed in a ratio of $4: 1$ and infused into a jugular vein of a dam at a rate of $0.25 \mathrm{ml} / \mathrm{min}$ for $15 \mathrm{~min}$ followed by $0.194 \mathrm{ml} / \mathrm{min}$ for the rest of the experiment. Maternal blood samples were secured from the tail vein and fetal samples from the axilla, as described above. Control animals were infused at similar rates with a saline solution $(0.154 \mathrm{~m}$ equivalent to $0.9 \mathrm{~g} / 100 \mathrm{ml}$ ).

\section{Preparation and Analyses of Tissues}

All samples were prepared and analyzed in duplicate. Approximately $1 \mathrm{~g}$ of maternal muscle and placenta was weighed, transferred to porcelain crucibles, and dried overnight in an oven at $100^{\circ}$. A total fetus was homogenized and 1 aliquot of approximately $1 \mathrm{~g}$ was similarly treated. Samples were reweighed following drying and transferred to a muffle furnace for $16 \mathrm{~h}$ at $450^{\circ}$. One milliliter of hot $0.5 \mathrm{~N}$ nitric acid was added to the dried sample and the solution centrifuged at $30,000 \times g$ for $10 \mathrm{~min}$ to clear it of minute particles of residue that might obstruct the flame photometer during $\mathrm{Na}$ and $\mathrm{K}$ analyses.

\section{Statistics}

Regressions (slopes and correlation coefficients), $t$ tests, and standard errors of the mean were determined on a computer [10].

Table I. Test diet ${ }^{1}$

\begin{tabular}{lclc}
\hline Diet & $\mathrm{g} / \mathrm{kg}$ & \multicolumn{1}{c}{ Basic salt mixture composition, \% } \\
\hline Casein & 200.0 & $\mathrm{CaCO}_{3}$ & 20.94 \\
Sucrose & 655.92 & $\mathrm{Ca}_{10}(\mathrm{OH})_{2}\left(\mathrm{PO}_{4}\right)_{6}$ & 41.00 \\
Fiber, nonnutritive & 20.00 & $\mathrm{CoCl}_{2} \cdot 6 \mathrm{H}_{2} \mathrm{O}$ & 0.02 \\
Corn oil & 70.00 & $\mathrm{CuSO}_{4} \cdot 5 \mathrm{H}_{2} \mathrm{O}$ & 0.15 \\
Vitamin supplement GBI & 9.08 & $\mathrm{FeCl}_{3} \cdot 6 \mathrm{H}_{2} \mathrm{O}$ & 4.65 \\
& & $\mathrm{MgSO}_{4}$ & 19.70 \\
& & $\mathrm{MnSO}_{4} \cdot \mathrm{H}_{2} \mathrm{O}$ & 0.40 \\
& & $\mathrm{NaI}_{2}$ & 0.014 \\
& & $\mathrm{Na}_{2} \mathrm{HPO}_{4}$ & 14.80 \\
& & $\mathrm{ZnSO}_{4} \cdot 7 \mathrm{H}_{2} \mathrm{O}$ & 0.116 \\
\hline
\end{tabular}

${ }^{1}$ Normal diet, $40 \mathrm{~g}$ of basic salt mixture, $5 \mathrm{~g} \mathrm{NaCl}$, and $12 \mathrm{~g} \mathrm{KCl}$ were added to $955 \mathrm{~g}$ of diet; $\mathrm{K}$ deficient, $\mathrm{KCl}$ was omitted; $\quad \mathrm{Na}$ deficient, $\mathrm{Na}_{2} \mathrm{HPO}$ was omitted from the basic salt mixture and $0.81 \mathrm{~g} \mathrm{NaCl}$ was added per kilogram diet.

${ }^{2}$ General Biochemicals, Inc., catalog no. 40060 . 
Results

Potassium

Studies of $\mathrm{K}$ levels in serum require careful surgical technique. MANIEY [4] has stressed that changes introduced by such factors as ether anesthesia and manipulations of the fetus might interfere with adequate oxygenation. He suggests that the wide variations reported in the literature for 'normal' values for serum $\mathrm{K}$ in the fetus probably reflect differences in methodology. For this reason it was important to use a standard technique and to establish control values.

In the present investigations we used sodium pentobarbital for anesthetic because it does not appear to affect blood levels of $\mathrm{K}$ [4]. The fetuses were gently delivered by hysterotomy into a $37^{\circ}$ saline bath, and the fetus and placenta were carefully inspected to make certain that the circulation was active. Fetal blood was collected quickly and easily from the axilla immediately after severing the umbilical vessels and removing the fetus from the bath. Although it is impossible to be certain that the levels obtained were the same as those that exist in utero, some confidence is provided by the constancy of the fetal blood levels in the control series. With the exception of three control animals, in which the maternal level was below $4 \mathrm{mEq} /$ liter (fig. 1), fetal levels closely approximated those in the mother (fetal to maternal ratio of 1.08). MANIEY [4] found maternal and fetal levels essentially equal at term.

A reduction in the $\mathrm{K}$ concentration in plasma was readily induced by removing $K$ from the diet. By the end of week 1 of gestation, when the blood was first sampled, the average concentration was $2 \mathrm{mEq} / \mathrm{liter}$ lower than that of the control group, and this difference was maintained throughout pregnancy (table II). By the end of the pregnancy, hypokalemia was severe.

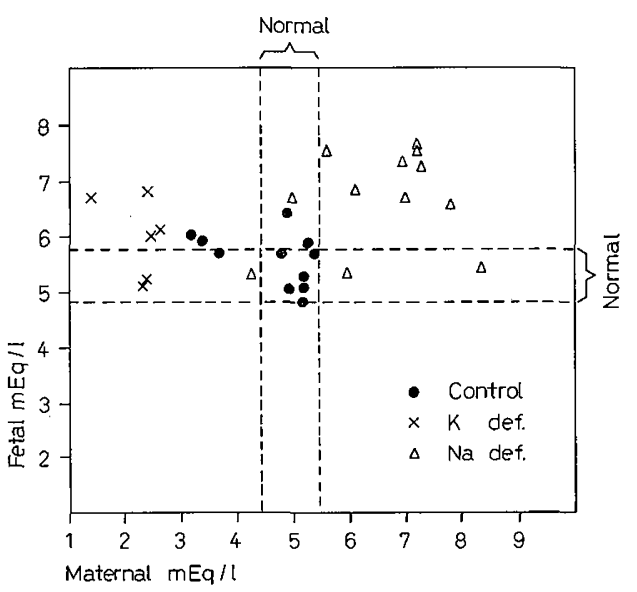

Fig.1. Relation of maternal and fetal plasma potassium. Interrupted lines indicate normal range.
The animals were sluggish, with ruffled fur, and refused their feedings. At hysterotomy, the fetuses were normal in number, responded vigorously to stimulation, but were small, weighing $0.5-1.0 \mathrm{~g}$ less than control fetuses.

The relation of $\mathrm{K}$ concentrations in maternal and fetal plasma is presented in figure 1. For unknown reasons, three mothers offered the control diets had distinctly low $\mathrm{K}$ levels in plasma. These rats differed from those on potassium-deficient diets in that the hypokalemia appeared acutely at the end of pregnancy, and the rats did not appear ill. Whatever the reason, low maternal $\mathrm{K}$ levels are not paralleled by reductions in fetal $\mathrm{K}$ level in plasma. In fact, the mean fetal $\mathrm{K}$ value was slightly higher in the potassium-deficient

Table II. Maternal blood levels

\begin{tabular}{|c|c|c|c|}
\hline \multirow[t]{2}{*}{ Diet } & \multirow[t]{2}{*}{ No. ${ }^{1}$} & \multicolumn{2}{|c|}{$7-8$ days $^{2}$} \\
\hline & & $\mathrm{Na}$ & $\mathrm{K}$ \\
\hline Control & 8 & $136 \pm 1.3^{3}$ & $5.7 \pm 0.3^{3}$ \\
\hline $\mathrm{K}$ deficient & 4 & $137 \pm 2.5$ & $3.6 \pm 0.3$ \\
\hline $\mathrm{Na}$ deficient & 9 & $140 \pm 0.5$ & $5.5 \pm 0.2$ \\
\hline \multirow[t]{2}{*}{ Diet } & \multirow[t]{2}{*}{ No. } & \multicolumn{2}{|c|}{ 14-26 days } \\
\hline & & $\mathrm{Na}$ & $\mathrm{K}$ \\
\hline Control & 9 & $136 \pm 1.0$ & $5.6 \pm 0.2$ \\
\hline $\mathrm{K}$ deficient & 4 & $136 \pm 1.0$ & $3.8 \pm 0.4$ \\
\hline $\mathrm{Na}$ deficient & 12 & $135 \pm 0.5$ & $5.0 \pm 0.3$ \\
\hline \multirow[t]{2}{*}{ Diet } & \multirow[t]{2}{*}{ No. } & \multicolumn{2}{|c|}{18 days } \\
\hline & & $\mathrm{Na}$ & $\mathrm{K}$ \\
\hline Control & 5 & $135 \pm 0.1$ & $5.4 \pm 0.3$ \\
\hline $\mathrm{K}$ deficient & & - & - \\
\hline $\mathrm{Na}$ deficient & 9 & $132 \pm 1.3$ & $6.0 \pm 0.2$ \\
\hline \multirow[t]{2}{*}{ Diet } & \multirow[t]{2}{*}{ No. } & \multicolumn{2}{|c|}{21 days } \\
\hline & & $\mathrm{Na}$ & $\mathrm{K}$ \\
\hline Control & 11 & $130 \pm 1.1$ & $4.6 \pm 0.25$ \\
\hline $\mathrm{K}$ deficient & 6 & $133 \pm 2.5$ & $2.3 \pm 0.18^{5}$ \\
\hline $\mathrm{Na}$ deficient & 9 & ${ }^{4} 123 \pm 2.0^{5}$ & ${ }^{4} 6.9 \pm 0.5^{5}$ \\
\hline
\end{tabular}

1 Number of animals.

2 Days of gestation.

${ }^{3}$ Mean in $\mathrm{mEq} /$ liter sem.

${ }^{4}$ Omitted from these means are the three most hyponatremic animals because blood samples had not been obtained at 18 days gestation.

${ }^{5}$ Differs from control $P<0.01$. 
animals, but this difference was not statistically significant (table III).

Rats on the sodium-deficient diet developed a hyperkalemia (fig. 1). The elevation in the maternal $\mathrm{K}$ level was an expected concomitant of the hyponatremia. Under these circumstances, the fetal $\mathrm{K}$ level tends to parallel the maternal, producing a significant fetal hyperkalemia (table III).

To avoid the criticism that elevations in fetal $\mathrm{K}$ values in plasma were not the result of the maternal hyperkalemia but were produced by the same secondary factors that caused the maternal hyperkalemia, $\mathrm{K}$ solutions were infused into a series of pregnant animals.
If the maternal hyperkalemia was maintained for $2 \mathrm{~h}$, fetal $\mathrm{K}$ values rose (table IV). The latent period probably represented the time necessary to saturate the various fetal pools before the rise in plasma $\mathrm{K}$ could occur.

The $\mathrm{K}$ concentration in the placenta following $\mathrm{K}$ deprivation reflects the variations in plasma concentration in the mother, but the range of variation was very much reduced (table III). A $50 \%$ reduction in $\mathrm{K}$ concentration in maternal plasma was associated with a reduction of about $8 \%$ in the placenta. There was one exceptionally low value in the placenta associated with an extremely low level in the mother (1.4

Table III. Effect of diet on potassium concentrations in plasma and tissues

\begin{tabular}{|c|c|c|c|c|c|c|}
\hline \multirow[t]{2}{*}{ Diet } & \multirow[t]{2}{*}{$\begin{array}{l}\text { No. of } \\
\text { animals }\end{array}$} & $\begin{array}{c}\text { Maternal } \\
\text { plasma level }\end{array}$ & $\begin{array}{c}\text { Fetal } \\
\text { plasma level }\end{array}$ & $\begin{array}{l}\text { Maternal } \\
\text { muscle }\end{array}$ & Placenta & Fetus \\
\hline & & \multicolumn{2}{|c|}{$\overline{\mathrm{mEq} / \text { liter }}$} & \multicolumn{3}{|c|}{$\mathrm{mEq} / \mathrm{kg}$} \\
\hline $\begin{array}{l}\text { Control } \\
\mathrm{K} \text { deficient } \\
\mathrm{Na} \text { deficient }\end{array}$ & $\begin{array}{r}11 \\
6 \\
12\end{array}$ & $\begin{array}{l}4.61 \pm 0.25 \\
2.3 \pm 0.18^{1} \\
6.6 \pm 0.34^{1}\end{array}$ & $\begin{array}{l}5.5 \pm 0.15 \\
6.0 \pm 0.27 \\
6.6 \pm 0.25^{1}\end{array}$ & $\begin{array}{l}86 \pm 2.9 \\
60 \pm 1.8\end{array}$ & $\begin{array}{l}54 \pm 1.2 \\
50 \pm 2.1^{2}\end{array}$ & $\begin{array}{l}54 \pm 0.9 \\
49 \pm 2^{1}\end{array}$ \\
\hline
\end{tabular}

1 Differs from control $P<0.01$.

${ }^{2}$ Differs from control $P<0.05$.

Table IV. Electrolyte concentrations in maternal and fetal plasma ${ }^{1}$

\begin{tabular}{|c|c|c|c|c|c|}
\hline \multirow[t]{3}{*}{ Infusion solutions } & \multirow{3}{*}{$\begin{array}{l}\text { Infusion } \\
\text { time, min }\end{array}$} & \multicolumn{4}{|c|}{ Plasma levels } \\
\hline & & \multicolumn{2}{|c|}{ Potassium, mEq/liter } & \multicolumn{2}{|c|}{ Calcium, mEq/liter } \\
\hline & & Maternal & Fetal & Maternal & Fetal \\
\hline \multirow[t]{3}{*}{$\mathrm{NaCl}(0.154 \mathrm{M}$ equivalent to $0.9 \mathrm{~g} / 100 \mathrm{ml})$} & 120 & 5.5 & 6.2 & 4.7 & 5.3 \\
\hline & 120 & $6.3^{2}$ & 6.5 & 3.9 & 5.0 \\
\hline & 90 & 4.3 & 6.1 & 4.5 & 4.8 \\
\hline $\mathrm{KCl}(0.154 \mathrm{~m}$ equivalent to $1.15 \mathrm{~g} / 100 \mathrm{ml})$ & 120 & $>10.0$ & $>10.0$ & 5.8 & 5.1 \\
\hline \multirow[t]{9}{*}{$\mathrm{CaCl}_{2}(0.11 \mathrm{~m}$ equivalent to $1.22 \mathrm{~g} / 100 \mathrm{ml}) 4: 1$} & 120 & 9.8 & 7.4 & 8.0 & 5.1 \\
\hline & 120 & 9.4 & 7.0 & 7.1 & 4.8 \\
\hline & 120 & 9.3 & 9.1 & 8.1 & 5.9 \\
\hline & 120 & 14.6 & 10.0 & - & - \\
\hline & 120 & 11.4 & 10.6 & - & - \\
\hline & 90 & $10.4^{3}$ & 6.9 & 6.0 & 5.3 \\
\hline & 90 & 13.1 & 6.5 & 6.5 & 6.9 \\
\hline & 90 & 8.3 & 6.1 & 6.0 & 4.8 \\
\hline & 90 & 8.4 & 6.0 & 4.0 & 6.3 \\
\hline
\end{tabular}

1 Pregnant rats were infused intravenously at rates which maintained the maternal potassium levels at approximately the levels indicated. Within $2 \mathrm{~h}$, the fetal potassium levels increased in response to maternal hyperkalemia. Values indicate plasma levels at termination of the experiment.

${ }^{2}$ Potassium level at $90 \mathrm{~min}$. Hemolysis in final sample prevented accurate analysis.

${ }^{3}$ Potassium level at $60 \mathrm{~min}$. 
$\mathrm{mEq} /$ liter). The $\mathrm{K}$ concentration of the total fetus also remained relatively constant in the face of maternal hypo- and hyperkalemia (table III).

The relative constancy of composition of fetal tissues may be contrasted with the much greater variability in $\mathrm{K}$ concentration in maternal muscle (table III). The maternal hypokalemia was accompanied by a considerable fall in $\mathrm{K}$ concentration in muscle. These observations parallel closely those made by STEWART and WeLt [6] in similar studies on $\mathrm{K}$ deprivation.

\section{Sodium}

The effect of the sodium-deficient diet on the pregnant rats was less consistent than the potassiumdeficient diet. The maternal $\mathrm{Na}$ level in plasma was

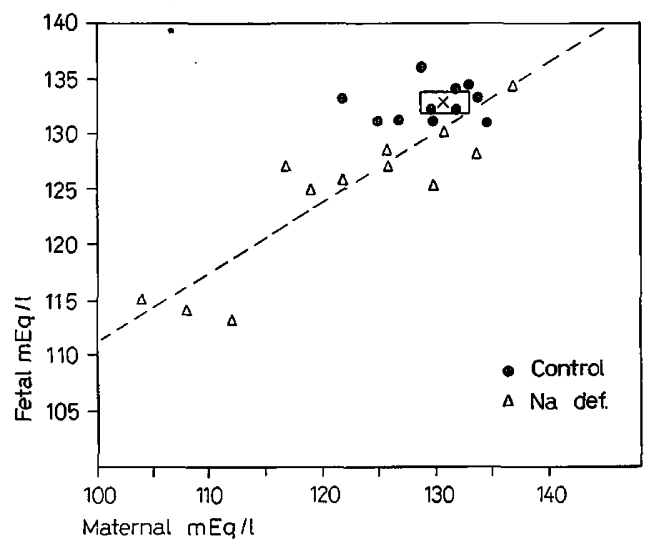

Fig. 2. Relation of maternal and fetal plasma sodium. Small box indicates mean of control values \pm twice the standard error of the mean. Regression line of sodiumdeficient fetuses is indicated. Control values do not form a regression line.

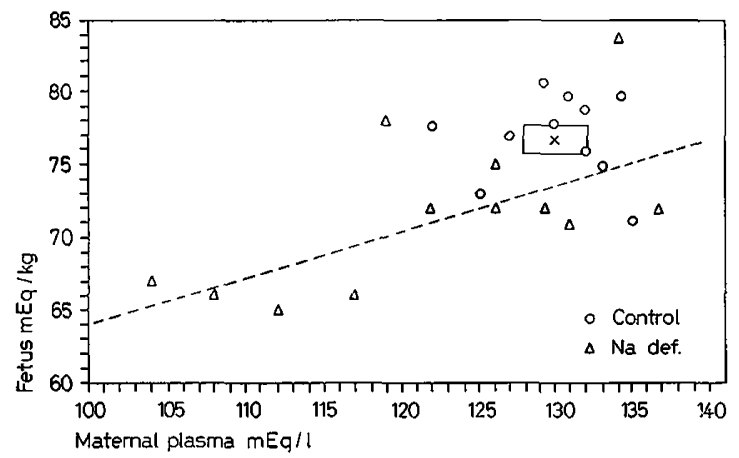

Fig.3. Relation of sodium concentration in the fetus to the maternal plasma sodium. Small box indicates mean of control values \pm twice the standard error of the mean. maintained within normal limits until day 18 of gestation when there was a slight reduction in mean $\mathrm{Na}$ concentration and elevation of K (table III). Samples were not obtained at this time in the three animals that were most hyponatremic at term, and $\mathrm{Na}$ reduction may have been more evident in them.

With the reduction in plasma $\mathrm{Na}$ in the mother, there was also a reduction in plasma $\mathrm{Na}$ in the fetus (fig.2). The correlation of maternal and fetal levels in plasma was high (correlation coefficient of regression, $0.91)$ though the reduction in the fetus was not as great as in the mother (slope of regression, 0.60 ). The $\mathrm{Na}$ concentration in the fetal tissues of the experimental animals (mean $71.7 \mathrm{mEq} / \mathrm{kg}$ ) was also significantly lower than that in the control fetuses (mean 77.1 $\mathrm{mEq} / \mathrm{kg} \pm 0.92, P=<0.01$ ). Since the weights of the sodium-deficient fetuses did not differ from the controls, this represents a decrease in total fetal Na. Correlation of maternal $\mathrm{Na}$ levels with total fetal $\mathrm{Na}$ levels in plasma was not as good as with fetal plasma levels (correlation coefficient, 0.64 ), and the slope of the regression (0.34) was less (fig. 3 ).

KIRKSEY and co-workers [3], in a similar study in rats, concluded that the fetuses of sodium-deficient animals maintained normal plasma levels despite considerable reductions in the maternal levels. Their figures reveal a reduction in the mean values of the test fetuses $(4 \mathrm{mEq} /$ liter $)$ with a large standard error so that statistical significance was not achieved. Evidently, the Na level in some of the fetus fell considerably more than the means would indicate. Phillrps and Sundaram [5] produced acute $\mathrm{Na}$ depletions in the pregnant ewe by draining saliva from the parotid, and noted depressions in fetal plasma $\mathrm{Na}$ similar to those we have observed in the present study.

\section{Discussion}

It is a common clinical observation that a normal wellnourished infant may be delivered from a mother suffering from malnutrition. From this observation has developed the concept that the fetus exists in utero as a parasite, with its nutritional needs taking precedence over those of the mother. The present study explores some of the mechanisms and the limitations of the concept as it pertains to the two univalent ions, $\mathrm{K}$ and $\mathrm{Na}$.

The opportunity for a fetus to scavenge a specific nutrient from the mother depends in the first instance on the availability of that material in maternal tissue. The nutrient must not only be present in the mother but must exist in mobilizable form. The second major factor in providing the nutrient to the fetus is the ability of the placenta to extract it from the maternal 
plasma and transfer it, if necessary against a gradient into the fetal circulation.

The concentrations of $K$ are normally high in maternal and fetal tissues and low in plasma. Under the conditions of this experiment, $\mathrm{K}$ was removed completely from the diet so that the growing fetus must derive its supply from maternal tissues. Consequently, in plasma, the $\mathrm{K}$ concentration falls to approximately one-half the normal level and is associated with a decrease in the concentration in maternal muscle that is not quite as extreme.

Despite this dramatic change in the mother, representing the external environment of the fetus, the fetus succeeds in maintaining its internal milieu relatively unchanged. This apparently results from the remarkable ability of the placenta to transport $\mathrm{K}$ into its own tissues and into fetal plasma against a variable gradient to a relatively constant concentration, despite severe degrees of maternal hypokalemia. The net result is that $\mathrm{K}$ is withdrawn in large amounts from maternal tissues and made available to the fetus.

Despite a $50 \%$ fall in the $\mathrm{K}$ concentration in the maternal plasma, the fetal concentration in plasma was not reduced at all (fig. 1), and the concentration in fetal tissues, the placenta and fetus, was reduced only about $8 \%$ (table III). The fetuses of the potassium-deficient mothers were generally smaller than those of the control animals, averaging 0.5-1.0 g less. It is possible that the small size resulted from the minor reductions in $\mathrm{K}$ concentration, but it may also have resulted from secondary systemic disturbances in the mothers. Potassium-deficient mothers were evidently ill towards term, with ruffled fur, sluggish behavior, and severe anorexia.

The results with $\mathrm{Na}$ were entirely different. The sodium-deficient diet contained about $4 \%$ of the amount of $\mathrm{Na}$ found in the control diet. On this diet, some of the rats were able to maintain normal plasma concentrations of $\mathrm{Na}$ throughout pregnancy. In most instances, a slight fall in $\mathrm{Na}$ levels was noted by day 18 of gestation, becoming more severe by term. The variability in results must be attributed to differences in the efficiency of compensatory mechanisms among the animals.

Examination of figures 1 and 2 reveals a profound difference between the effects of maternal hypokalemia and hyponatremia on fetal homeostasis. Whereas reductions in maternal $\mathrm{K}$ concentrations in plasma of $50 \%$ had no significant effects on fetal $\mathrm{K}$ levels, relatively minor reductions in maternal $\mathrm{Na}$ levels were clearly reflected in fetal $\mathrm{Na}$ concentrations. Although the fall in fetal $\mathrm{Na}$ was not as severe as the fall in maternal $\mathrm{Na}$, protection of the fetus against hyponatremia was of an entirely different order of magnitude than protection against hypokalemia.
In interpreting these results, certain fundamental considerations must be kept in mind. The total amount of $\mathrm{Na}$ in the pregnant rat approximates that of $\mathrm{K}$ but is distributed in the tissues at concentrations that are relatively lower than the concentrations in maternal and fetal plasma. Sodium is the major determinant of the osmolarity of the plasma and extracellular fluids. It has been demonstrated in rabbits that changes in plasma osmolarity induced in the doe are quickly reflected in the fetus [1]. Reductions in maternal $\mathrm{Na}$ in the pregnant rat would be expected to cause a fall in plasma osmolarity and a parallel change in the fetus. Thus, the fall in Na concentration in the fetal plasma induced by maternal hyponatremia may have been produced by a transfer of water from the mother, by a reduction in total $\mathrm{Na}$ content, or both. It is likely that differences in $\mathrm{Na}$ concentration in the two circulations must be balanced by some other osmotically active constituent. No attempt was made in the present study to determine the nature of the osmotic balance.

The physiological adjustments during pregnancy associated with deprivation of these two univalent ions stand in sharp contrast, undoubtedly reflecting their different roles in metabolism. In the face of $K$ deprivation with severe maternal hypokalemia, the placenta serves primarily in a defensive role to maintain fetal concentrations relatively unaltered; however, the placenta is relatively ineffective against maternal hyperkalemia. The major defense against $\mathrm{Na}$ deprivation lies in the ability of maternal compensatory mechanisms to maintain the maternal $\mathrm{Na}$ concentration. The defensive role of the placenta is relatively limited.

\section{References and Notes}

1. Dancis, J., Worth, M. and Schneidau, P.B.: Effect of electrolyte disturbances in the pregnant rabbit on the fetus. Amer.J. Physiol. 188: 535 (1957).

2. Hartroft, P.M. and Eisenstein, A.B.: Alterations in the adrenal cortex of the rat induced by sodium deficiency: correlation of histologic changes with steroid hormone secretion. Endocrinology, Springfield 60: 641 (1957).

3. Kirksey, A.; Pike, R.L. and Callahan, J.A.: Some effects of high and low sodium intakes during pregnancy in the rat. II. Electrolyte concentrations of maternal plasma, muscle, bone and brain and of placenta, amniotic fluid, fetal plasma and total fetus in normal pregnancy. J. Nutr. 77: 43 (1962).

4. Maniey, J. : Influence des aggressions sur la teneur en potassium et en sodium du plasma chez la ratte gestante ou non gestante et chez le fœtus. Ann. Endocrin., Paris 28: 46 (1967). 
5. Phillips, G.D. and Sundaram, S. L. : Sodium depletion of pregnant ewes and its effects on foetuses and foetal fluids. J. Physiol., Lond. 184: 889 (1966).

6. Stewart, E.L. and Welr, L.G.: Protection of the fetus in experimental potassium depletion. Amer. J. Physiol. 200: 824 (1961).

7. General Biochemicals Company, Chagrin Falls, $\mathrm{OH}$.

8. Charles River Breeding Laboratories, Inc., Wilmington, MA.

9. We are indebted to Dr. Bernard Altshuler for advice concerning the presentation of these data.
10. Olivetti Programma 101, using standard programs provided by Olivetti Underwood, New York, NY.

11. Aided by National Institute of Child Health and Human Development Grant no. HD00462-14. Dr. DANcrs is a Career Investigator, National Institute of Child Health and Human Development.

12. Requests for reprints should be addressed to: Joseph Dancis, M.D., Department of Pediatrics, New York University Medical Genter, School of Medicine, 550 First Avenue, New York, NY 10016 (USA).

13. Accepted for publication December 16, 1969. 